\title{
A Measure of EFL Public Speaking Class Anxiety: Scale Development and Preliminary Validation and Reliability
}

\author{
Kriangkrai Yaikhong ${ }^{1} \&$ Siriluck Usaha ${ }^{1}$ \\ ${ }^{1}$ School of Foreign Languages, Institute of Social Technology, Suranaree University of Technology, Thailand \\ Correspondence: Kriangkrai Yaikhong, School of Foreign Languages, Institute of Social Technology, Suranaree \\ University of Technology, Nakhon Ratchasima 30000, Thailand. Tel: 664-422-4214 E-mail: \\ kriangkrai267@gmail.com
}

Received: September 2, 2012 Accepted: September 13, 2012 Online Published: October 19, 2012

doi:10.5539/elt.v5n12p23 URL: http://dx.doi.org/10.5539/elt.v5n12p23

\begin{abstract}
The present study contributes to developing a Public Speaking Class Anxiety Scale (PSCAS) to measure anxiety in the EFL public speaking class in the Thai context. Items were adopted from previous scales: Foreign Language Classroom Anxiety Scale (FLCAS) by Horwitz et al. (1986); Personal Report of Communication Apprehension (PRCA-24) and Personal Report of Public Speaking Anxiety (PRPSA-34) by McCroskey (1970); and Speaker Anxiety Scale (SA) by Clevenger and Halvorson (1992) based on their critical appraisals. Some minor changes in wordings of adopted items were made to a preliminary PSCAS and were validated. The preliminary PSCAS yielded an internal consistency of .84 using Cronbach's alpha coefficient when administered to 76 participants and was factor-analyzed to establish the construct and the final version. The factor analysis revealed that the PSCAS included the components of communication apprehension, test anxiety, fear of negative evaluation, and comfort in using English in a public speaking class.
\end{abstract}

Keywords: scale development, critical appraisal, factor analysis, validation, reliability

\section{Introduction}

In current EFL pedagogic situations, it is known that many students exhibit fear of foreign language speaking. To quote Kim (1998), in Asian EFL classrooms, students manifest less anxiety dramatically in the reading class than the conversation class and this leads to the intuitive feelings of both teachers and students that language classrooms requiring oral communication are found to be more anxiety-provoking than those requiring less speaking. In the Thai EFL context, addressing speaking skill has become a critical part of the processes of learning and teaching because it has been found to be extremely hard for Thai learners to master fluent speaking (Khamkhien, 2010). This can be attributed to the unnatural language often used and the lack of genuine interaction in the language classroom. Sethi (2006) asserts that generally Thais do not reach a level of proficiency high enough to perform well in speaking English. Boonkit (2010) reveals that in the Thai context undergraduate students are not able to speak English with confidence to communicate, especially in real situations with international speakers because they are anxious about making errors. Thus, strengths of English speaking skills are attributed to confidence and competence for them. Forman (2005) states that the unwillingness to communicate on the part of Thai EFL students is that Thai EFL students tend to lose natural feeling of meanings of what has been spoken, leading to the lack of confidence to perform in the medium of the target language, and according to Wariyachitra (2003), the lack of an opportunity to learn English in an English environment or the tendency for students to avoid interaction in daily life makes learning in Thailand unsuccessful.

As such, foreign language classroom anxiety has been proven to affect EFL learners' language performance depending on each individual's anxiety level in different learning situations (Young, 1986; Horwitz \& Young, 1991; MacIntyre \& Gardner, 1991; Phillips, 1992; and Aida, 1994). To measure the anxiety levels, the Foreign Language Classroom Anxiety Scale (FLCAS) by Horwitz et al. (1986) has been most frequently used to determine overall foreign language anxiety in the classroom, while in public speaking the most frequently employed scale has been the Personal Report of Communication Apprehension (PRCA-24) by McCroskey (1970), which measures anxiety in different dimensions, such as public speaking, talking in meetings or classes, talking in small groups, and talking in dyads. Accordingly, no research studies have been conducted to determine 
anxiety levels using a developed scale to tap into speaking anxiety in the public speaking class setting, specifically in the context of Thailand. Therefore, a Public Speaking Class Anxiety Scale (PSCAS) was developed to refine public speaking class anxiety in the Thai EFL context.

\section{Language and Speaking Anxiety in the Thai Context}

For anxiety regarding English speaking, Udomkit (2003) stated that the communication anxiety of the Basic Signal Officers in the English classroom at the Signal School was caused by the insufficient opportunity for students to participate in classroom communication, lack of confidence when communicating English in the classroom, and also by affective factors like interpersonal evaluation, classroom activities and methods, as well as self-esteem. Bunrueng (2008) investigated levels of anxiety and factors affecting anxiety in taking English for Communication course at Loei Rajabhat University. The findings concerned seven aspects: (1) English for Communication subject; (2) speaking anxiety; (3) listening anxiety; (4) reading anxiety; (5) writing anxiety; (6) teaching-learning activity anxiety, and (7) teaching media and evaluation anxiety. Of these, speaking anxiety was rated at a high level, whereas the others were rated medium. Specifically, it was found that students felt most anxious to speak English in an English class without preparation, did not brave to volunteer to answer questions, felt troubled when asked by the teacher, worried about the use of grammar, were embarrassed when they made mistakes, lost confidence in speaking, and were shy when speaking English with friends. When students' anxiety levels were compared based on their majors, the English major students and the Business English major students were found to have anxiety at a moderate level. Tasee (2009) studied the overall speaking anxiety of 963 Rajabhat University students majoring in English and revealed that Rajabhat University students majoring in English manifested speaking anxiety at a moderate degree and felt most anxious when they had to speak English. Tananuraksakul (2011) examined 69 Thai undergraduate students' levels of confidence and anxiety in spoken English in different speaking classes and reported that the students' confidence and anxiety were moderate because they felt shy to speak English to both Thai and foreigner professors. In addition, students' revelation that "they did not think they could speak English well" was ascribed to their very low level of confidence in speaking English and that statements such as "I worried about speaking with errors, taking oral tests, earning grades, and learning English" were ascribed to the high level of anxiety. Clearly, previous studies in language and speaking anxiety in the Thai context confirmed existing speaking anxiety experienced by Thai students.

\section{Critical Appraisals of Existing Language Anxiety Scales}

This part presents four existing language anxiety scales used to measure overall foreign language anxiety and public speaking anxiety levels. Each scale is described followed by factor analysis studies of the scales available and an account of discrepancies found after use.

\subsection{Foreign Language Classroom Anxiety Scale (FLCAS) by Horwitz et al. (1986)}

The Foreign Language Classroom Anxiety Scale (FLCAS) was developed by Horwitz et al. (1986). The FLCAS contains 33 items using a five-point Likert scale, which ranges from "Strongly Agree" to "Strongly disagree." It measures students' self-reports regarding anxiety by adding up the ratings on the 33 items. The FLCAS's construct comprises three dimensions: (1) fear of negative evaluation; (2) communication apprehension; and (3) test anxiety. The levels of anxiety based on this scale are categorized into three levels. The high anxiety level is represented by a score of more than 144, the moderate anxiety level a score of 108 to 144 , and little or no anxiety level less than 108 .

\subsubsection{Factor Analysis}

The studies into factor analysis of the FLCAS are as follows.

Aida (1994) did factor analysis of the FLCAS to investigate the underlying structure of the FLCAS's thirty-three items before adapting it for Japanese students. The analysis reported four factors: speech anxiety; fear of failing; comfort; and negative attitudes. Factor One, labeled speech anxiety, comprised Items \# 3, 13, 27, 20, 24, 31, 7, $12,23,33,16,1,21,29,4,9$, with the two items $(18,8)$ which were negatively loaded. Factor Two, labeled as a fear of failing, consisted of Items \# 10, 25, and 26, with one negatively loaded item (\#22). Factor Three, comfort, included Items \# 32, 11, 14. Factor Four, negative attitudes, was limited to one Item (\# 17) and one item (\# 5) was negatively loaded.

Pérez-Paredes and Martínez-Sánchez (2000-2001) carried out a study using a Spanish version of the Foreign Language Classroom Anxiety Scale (FLCAS) with reference to Aida's (1994) study. Based on the Principal Component Analysis with Varimax Rotation, they concluded that there were four factors as follows:

Factor One, labeled as communication apprehension, included items relevant to anxiety, shyness, and physical reactions towards speaking in a foreign language. The Items belonging to this factor were $\# 1,3,9,12,13,18,20$, 
24, 27, 31, 33. Factor Two was labeled as anxiety about the language learning process and situations. Items indicating anxiety triggers like circumstances and components relevant to foreign language learning context in this factor included Items \# 4, 7, 15, 16, 23, 25, 29, 30. Based on the analysis of this factor, Items \# 29, 15, 4 were associated with students' fear of not understanding their teacher. Items \# 7, 23 were an indication of students' fear of being less proficient than their classmates. Items \# 25, 30 were related to fear of failing in learning a foreign language and Item \# 16 was indicated as a tension in class. Factor Three, labeled as comfort in using English both inside and outside the classroom, comprised Items \# 14, 32, each of which reflected students' ease when using English at school or with native speakers outside. It also included Item \# 8, which was an indication of attitudes towards test taking. The last factor, negative attitudes towards language learning, included Items \# 6,17. These last two items were a label of learners' feelings in relation to anxious experience in foreign language learning.

In addition to Aida (1994) and Pérez-Paredes and Martínez-Sánchez (2000-2001), Tóth (2008) studied foreign language anxiety scale for Hungarian learners of English. In the study, Tóth did an analysis of the factor loading and found that there were eight factors in the FLCAS. The first factor, labeled as speaking performance and fear of negative evaluation, comprised thirty items out of thirty-three on the FLCAS. This factor comprised Items \# 27, 9, 18, 24, 1 (anxiety related to speaking English in a classroom context), Items \# 20, 3 (anxiety over being called on), Items \# 7, 23 (feelings of being less competent than others in the target language), and Items \# 28, 16, 12 (self-perceived anxiety levels in the English class). Other items with appreciable loading in this factor were $10,2,8,19$, and 21(test anxiety), Items \# 4, 29, (receiver anxiety, and Items \# 32, 14, (apprehension about communicating with native speakers of English). The second factor, labeled as test anxiety and fear of inadequate classroom performance, included Item \# 21 (an indication of fear of unsuccessful test performance), Item \# 8 (feelings of failure to perform well in the classroom context), Item \# 30 (a fear of not being able to cope with the task of language learning, Item \# 25 (a worry over getting left behind), item \# 10 (a fear of failing to meet the requirement), and Item \# 6 (feeling anxious despite being well prepared for class). All the items mentioned except Item \# 21, which appreciably loaded, received a strong load, whereas the other two remaining Items $(\# 14,32)$ received a negative load. The items with the strong load were considered a global foreign language anxiety. The third factor, labeled as attitudes towards English class, consisted of Item \#17 (inclinations to skip class), Item \# 6 (task-irrelevant cognition during classes), Item \#5 (exploring whether students would mind taking more of these classes), and Item \#22 (feeling pressured to prepare well for classes). All the items here were strongly loaded except Items \# 5, 17, which were marginally loaded. The fourth factor, teacher-related anxiety, included Item \# 19 (anxiety over getting corrected), Item \# 15 (anxiety of not comprehending the teacher's correction), and Items \# 29 and 4 (psychological effects of not understanding what the teacher is saying in the target language). The Items \# 15, 19 received a strong load, whereas 29 and 4 received an appreciable load. The last four factors of this analysis seemed not to define important dimensions of the scale; therefore, they were not attached to any labels. Obviously, all three of the above-cited studies found four factors of foreign language anxiety: speaking apprehension, fear of negative evaluation, fear of not performing well, and classroom-related anxiety.

\subsubsection{Discrepant Results Found Using the FLCAS}

Since the FLCAS was introduced as an instrument to measure foreign language classroom anxiety levels, many researchers; thereafter, have widely administered it in broad ranges of research studies pertaining to foreign language classroom anxiety. However, the results obtained through the scale were reported to be complex. Price (1991) found a negative connection between foreign language anxiety and foreign language aptitude, but a positive correlation between foreign language anxiety and test anxiety and public speaking anxiety after the administration of the FLCAS. Phillips (1992) revealed that language anxiety had a modest debilitating impact on oral exam performance and oral proficiency exam for the university students in the third-semester French class administered by the FLCAS. Chen and Chang (2004) studied variables related to learning English as a foreign language based on Horwitz's FLCAS and Sparks' and Ganschow's Foreign Language Screening Instrument (FLSI) with 1,187 Taiwanese college students. The findings indicated that the difficulties found in learning English accounted by $36.8 \%$ of the variance based on the FLCAS without considering the history of learning language and test characteristics as predictors for students' anxiety levels. Thus, the researchers concluded that the development of anxiety regarding learning a language was due to the history of language learning problems of the students. In an analysis of the FLCAS' items by Sparks \& Ganschow (1991), they speculated that the FLCAS captured only the students' perceptions and attitudes about language as well as their feelings about anxiety. They went further to say that all the items on this scale were primarily based on the authors' experiences with college students who had a "support group" for college students involved with foreign language learning. 
To conclude, the construct of the FLCAS was found obscure; thus, a breadth of research studies into this domain showed discrepant results.

\subsection{Personal Report of Communication Apprehension (PRCA-24) by McCroskey (1970)}

The PRCA originally varied in forms used as a self-report to measure trait-like communication apprehension. Those original forms were 20-item (McCroskey, 1970), 10-item (McCroskey, 1978), 25-item (McCroskey, 1978), and 24-item (McCroskey, 1982) scales. The 10, 20, and 25-item versions were found to contain a disproportionate number of items designed to tap trait -like communication apprehension across multiple communication contexts. The PRCA-24, the latest version, extracted from PRPSA-34, included 6 items for each of the four dimensions: public speaking, talking in meetings or classes, talking in small groups, and talking in dyads. McCroskey et al. (1985) stated that the items on PRCA-24 represented common communication situations in four dimensions. The first dimension, speaking in small groups, comprised Items \# 1-6. The second dimension, speaking in meetings, comprised Items \# 7-12. The third dimension, speaking in dyads, comprised Items \# 13-18. The last dimension, public speaking, included Items \# 19-24. The overall approach of the items on the scale represented the broad-based trait- like orientation, which is what communication apprehension was assumed to be. The PRCA-24 provided sub-scores for each dimension. The levels of communication apprehension measured using this scale could range from high, moderate to low.

\subsubsection{Factor Analysis of the PRCA-24}

According to the factor analysis done by Kearney, Beatty, Plax, and McCroskey, (1984), the item loading of PRCA-24 was reported in three factors. Factor One, labeled as group discussion, public meeting, and apprehension, comprised Items \# 1, 2, 3, 4, 6, 7, 8, 10, 11, 12 with the exclusion of Items \# 5, 9. Factor Two, labeled as inter- personal or dyadic communication and apprehension, consisted of Items \# 13, 14, 17, 18 with the exclusion of Items \# 15, 16. Factor Three, public speaking and apprehension, comprised Items \# 19, 20, 21, 23 with the exclusion of Items \# 22, 24. Based on the factor analysis of this scale, the items belonging to public speaking and apprehension were replicated for the development of the items in a PSCAS.

\subsubsection{Discrepant Results Found Using the PRCA-24}

The PRCA-24 measures communication apprehension in different dimensions, not only in a public speaking context. Its construct heavily depicts either trait-like anxiety or state-like anxiety in the psychological aspect. Behnke and Sawyer (1998) stated that to investigate the more specific periods or contexts using the wind-band or general trait measures tended to limit the degree of measurement precision. Frantz, Marlow and Wathen (2005) mentioned in their research into communication apprehension and its relationship to gender and college year that female business students were reported to have higher communication apprehension than males; however, males majoring in accounting were found to have a higher level of communication apprehension than females using this scale. Daly (1991) pointed out that PRCA-24 was found inappropriate in foreign language classroom anxiety research because the items tended to measure anxiety relevant to speech giving rather than common practices in foreign language classroom. Besides, items regarding listening considered a common source of anxiety associated with communication apprehension in a foreign language classroom setting are not included in this scale (Vogely, 1999). As such, the results found in using the PRCA-24 may have been inconclusive.

\subsection{Personal Report of Public Speaking Anxiety (PRPSA-34) by McCroskey $(1970,1992)$}

The PRPSA-34 arose from McCroskey's (1970) perspective that Personal Report of Confidence as a Speaker by Gilkinson (1942) forced responses to fit on a true-false scale. Thus, McCroskey constructed PRPSA-34 so as to increase precise measurement of communication apprehension in this area of studies. The PRPSA-34 was a uni-dimensional questionnaire with 34 statements concerning feelings related to giving a speech and its presentation in a public context. Each item expressed a degree of communication apprehension with a Likert-type scale: strongly agree, agree, undecided, disagree, and strongly disagree, respectively. Based on McCroskey and Richmond (1992), the score of this scale was divided into five levels of anxiety: a score of 34-84 indicated low anxiety, 85-92 moderately low anxiety, 93-110 moderate anxiety, 11-119 moderate high anxiety, and 120-170 high anxiety, respectively. Arguably, the PRPSA-34 was designed and used primarily to identify highly anxious students. According to Pribyl, Keaten and Sakamoto (2001), discrepant results using PRPSA-34 were found and that public speaking anxiety and English ability were not significantly correlated. Theoretically, the finding did not support the claim that there was a significant correlation between English ability and public speaking anxiety. In addition, the PRPSA-34 was heavily weighted with items on communication in public speaking contexts. Most importantly, these items were employed to measure public speaking anxiety in real situations rather than in the public speaking class setting. 


\subsection{Speaker Anxiety Scale (SA) by Clevenger and Halvorson (1992)}

The Speaker Anxiety Scale (SA) was used mainly to measure state anxiety because it was designed to assess situational anxiety in relation to public speaking (Clevenger \& Halvorson, 1992). This scale was developed to be the PRCA-State Version 2 and renamed "Speaker Anxiety Scale." It consisted of 32 items measuring nine factors: (a) pre-speech tension; (b) shyness; (c) confusion; (d) physiological activation; (e) post-speech activation; (f) environmental threat; (g) positive anticipation; (h) poise; and (i) wants more. As indicated by the literature review, the SA provided an overall score and was found the most current instrument particularly used to measure state anxiety in communication. It covered a broad range of speaking contexts, specifically from the psychological aspect. Arguably, many items found were a replication of items of the PRPSA-34 and PRCA-24 by McCroskey (1970) and the FLCAS by Horwitz et al. (1986). State anxiety, which was the main construct of SA, was viewed as anxiety caused by generalized experiences of language learning unlike the situation-specific anxiety considered appropriate for foreign language classroom anxiety as stated by Gardner and McIntyre (1993). However, the SA covered a wide range of speaking contexts, but some of its items were relevant to public speaking class anxiety. Thus, a few such items relevant to public speaking in a classroom setting were considered, adopted, and adapted.

Based on the above mentioned, all the scales discussed above are used to measure anxiety in various contexts, not specifically in the EFL public speaking classroom context. Scovel (1978) mentioned that inconsistent results of the relationship between anxiety and foreign language achievement might be due to the different anxiety measures used in the studies, thus it was necessary for the researchers to specify the types of anxiety being measured and its relationship to other factors. In addition, research studies in language anxiety with inconclusive results were found because all the items do not measure all dimensions of anxiety in foreign language classes and might also measure extraneous variables. According to Gardner (1980), it is necessary to develop an appropriate scale to specifically capture language anxiety in contexts of second language learning. As thus, it was therefore necessary for the present study to develop a scale that would focus only on speaking anxiety in a public speaking class.

\section{Item Adoption and Adaptation of Existing Language Anxiety Scales}

\subsection{Item Selection and Consideration with Minor Changes in Wordings of Foreign Language Classroom Anxiety Scale}

The consideration for item selection to be included in a PSCAS was based on the studies on the FLCAS using factor analysis to refine foreign language classroom anxiety done by Aida (1994), Pérez-Paredes and Martínez-Sánchez (2000-2001), and Tóth (2008). According to the findings of these studies, the items analyzed as measures of speech anxiety, communication apprehension, and anxiety related to speaking English in a classroom context, considered as foreign language classroom speaking anxiety in the FLCAS, were Items \# 1, 3, 4, 7, 9, 12, 13 , 16, 18, 20, 21, 23, 24, 27, 29, 31, 33 (Aida, 1994; Pérez-Paredes \& Martínez-Sánchez, 2000-2001; and Tóth, 2008). These items with minor changes in wordings (for example, "speaking the foreign language" being replaced by "speaking English") were included to give a PSCAS face validity and reflect speaking anxiety in a public speaking class accordingly.

Item \# 1 "I never feel quite sure of myself while I am speaking English."

Item \# 3 "I tremble when knowing that I am going to be called on to speak English."

Item \# 4 was omitted because it was a learning process-related anxiety (Pérez-Paredes and Martínez-Sánchez, 2000-2001) and teacher-related anxiety (Tóth, 2008), which does not tap speaking anxiety in particular.

Item \# 7 "I keep thinking that other students are better at speaking English than I."

Item \# 9 "I start to panic when I have to speak English without preparation in advance."

Item \# 12 "In the speaking class, I can get so nervous I forget things I know."

Item \# 13 "It embarrasses me to volunteer to go out first to speak English."

Item \# 16 "Even if I am well prepared, I feel anxious about speaking English."

Item \# 18 "I feel confident while I am speaking English."

Item \# 20 "I can feel my heart pounding when I am going to be called on to speak English."

Item \# 21 "The more speaking tests I have, the more confused I get."

Item \# 23 "I always feel that the other students speak English better than I do." 
Item \# 24 "I feel very self-conscious while speaking English in front of other students."

Item \# 27 "I get nervous and confused when I am speaking English."

Item \# 29 was omitted because it is related to students' fear of not understanding their teacher (Pérez-Paredes and Martínez-Sánchez, 2000-2001), which was called receiver anxiety (Tóth, 2008).

Item \# 31 "I am afraid that other students will laugh at me while I am speaking English."

Item \# 33 "I get nervous when the language teacher asks me to speak English which I have prepared in advance." 4.2 Item Selection and Consideration with Minor Changes in Wordings of the Personal Report of Communication of Apprehension-24

The selected Items \# $(19,20,21$, and 23) were included in a PSCAS based on the studies of the PRCA-24 using factor analysis by Kearney, Beatty, Plax, and McCroskey (1984). As indicated by the results, the dimension of a public speaking situation referred to as "Stage Fright" on the PRCA-24 comprised Item \# 19, 20, 21, 23. These items were mainly used to measure feelings in relation to giving speech and a presentation and, importantly, they elicited public speaking anxiety in relation to "Stage Fright." Thus, they all were adopted with minor changes in wordings accordingly.

Item \# 19 "I have no fear of speaking English."

Item \# 20 "Certain parts of my body feel very tense and rigid while speaking English."

Item \# 21 "I feel relaxed while speaking English."

Item \# 23 "I face the prospect of speaking English with confidence."

4.3 Item Selection and Consideration with Minor Changes in Wordings of the Personal Report of Public Speaking Anxiety-34

Items \# 33 of the PRPSA-34 was selected to be included in a PSCAS. As the PRPSA was the extraction version of the PRCA-24, many items on this scale were similar to that of the PRCA-24; therefore, only Item \# 33 was considered because it was relevant to speaking in the classroom setting. Minor changes in wordings were made as follows:

Item \# 33 "I feel anxious while waiting to speak English."

\subsection{Item Selection and Consideration with Minor Changes in Wordings of the Speaker Anxiety}

The items selected to be included in the PSCAS were Items \# 5, 7, 9, 11, 20, and 22. These items were found relevant to speaking anxiety in the classroom setting, especially in a public speaking class; thus, they were included with minor changes in wordings as follows:

Item \# 5 "I look forward to expressing my ideas in English."

Item \# 7 "I enjoy the experience of speaking English."

Item \# 9 "I want to speak less because I feel shy while speaking English."

Item \# 11"I dislike using my voice and body expressively while speaking English."

Item \# 20 "I have trouble to coordinate my movements while speaking English."

Item \# 22 "I find it hard to look the audience in the eye while speaking English."

Accordingly, items were rearranged as illustrated in Table 1 
Table 1. Preliminary 25-Item PSCAS

\begin{tabular}{|c|c|c|c|c|c|c|}
\hline \multirow{2}{*}{$\begin{array}{l}\text { Item } \\
\text { No }\end{array}$} & \multirow{2}{*}{$\begin{array}{l}\text { Statements adopted } \\
\text { adaptation in wordings }\end{array}$} & \multicolumn{5}{|l|}{ Opinion } \\
\hline & & $\begin{array}{l}(5) \\
\text { Strongly } \\
\text { Agree }\end{array}$ & $\begin{array}{l}\text { (4) } \\
\text { Agree }\end{array}$ & $\begin{array}{l}\text { (3) } \\
\text { Undecided }\end{array}$ & $\begin{array}{l}(2) \\
\text { Disagree }\end{array}$ & $\begin{array}{l}\text { (1) } \\
\text { Strongly } \\
\text { Disagree }\end{array}$ \\
\hline 1 & $\begin{array}{l}\text { I never feel quite sure of myself while I } \\
\text { am speaking English. }\end{array}$ & & & & & \\
\hline 2 & $\begin{array}{l}\text { I tremble when knowing that I am going } \\
\text { to be called on to speak English. }\end{array}$ & & & & & \\
\hline 3 & $\begin{array}{l}\text { I start to panic when I have to speak } \\
\text { English without a preparation in } \\
\text { advance. }\end{array}$ & & & & & \\
\hline 4 & $\begin{array}{l}\text { In a speaking class, I can get so nervous I } \\
\text { forget things I know. }\end{array}$ & & & & & \\
\hline 5 & $\begin{array}{l}\text { I feel confident while I am speaking } \\
\text { English. }\end{array}$ & & & & & \\
\hline 6 & $\begin{array}{l}\text { I feel very self-conscious while speaking } \\
\text { English in front of other students. }\end{array}$ & & & & & \\
\hline 7 & $\begin{array}{l}\text { I get nervous and confused when I am } \\
\text { speaking English. }\end{array}$ & & & & & \\
\hline 8 & $\begin{array}{l}\text { I am afraid that other students will laugh } \\
\text { at me while I am speaking English. }\end{array}$ & & & & & \\
\hline 9 & $\begin{array}{l}\text { I get so nervous when the language } \\
\text { teacher asks me to speak English which I } \\
\text { have prepared in advance. }\end{array}$ & & & & & \\
\hline 10 & I have no fear of speaking English. & & & & & \\
\hline 11 & $\begin{array}{l}\text { I can feel my heart pounding when I am } \\
\text { going to be called on. }\end{array}$ & & & & & \\
\hline 12 & I feel relaxed while speaking English. & & & & & \\
\hline 13 & $\begin{array}{l}\text { It embarrasses me to volunteer to go out } \\
\text { first to speak English. }\end{array}$ & & & & & \\
\hline 14 & $\begin{array}{l}\text { I face the prospect of speaking English } \\
\text { with confidence. }\end{array}$ & & & & & \\
\hline 15 & $\begin{array}{l}\text { I enjoy the experience of speaking } \\
\text { English. }\end{array}$ & & & & & \\
\hline 16 & $\begin{array}{l}\text { The more speaking tests I have, the more } \\
\text { confused I get. }\end{array}$ & & & & & \\
\hline 17 & $\begin{array}{l}\text { Certain parts of my body feel very tense } \\
\text { and rigid while speaking English. }\end{array}$ & & & & & \\
\hline 18 & $\begin{array}{l}\text { I feel anxious while waiting to speak } \\
\text { English. }\end{array}$ & & & & & \\
\hline 19 & $\begin{array}{l}\text { I want to speak less because I feel shy } \\
\text { while speaking English. }\end{array}$ & & & & & \\
\hline 20 & $\begin{array}{l}\text { I dislike using my voice and body } \\
\text { expressively while speaking English. }\end{array}$ & & & & & \\
\hline 21 & $\begin{array}{l}\text { I have trouble to coordinate my } \\
\text { movements while speaking English. }\end{array}$ & & & & & \\
\hline 22 & $\begin{array}{l}\text { I find it hard to look the audience in my } \\
\text { eyes while speaking English. }\end{array}$ & & & & & \\
\hline 23 & $\begin{array}{l}\text { Even if I am very well-prepared I feel } \\
\text { anxious about speaking English. }\end{array}$ & & & & & \\
\hline 24 & $\begin{array}{l}\text { I keep thinking that other students are } \\
\text { better at speaking English than I. }\end{array}$ & & & & & \\
\hline 25 & $\begin{array}{l}\text { I always feel that the other students } \\
\text { speak English better than I do. }\end{array}$ & & & & & \\
\hline
\end{tabular}

\section{Validity, Reliability, and Anxiety Levels Using a PSCAS}

\subsection{Content Validity}

All of the items were validated by three teachers of English with over ten years of teaching experiences, one assistant professor and other two assistant professors with $\mathrm{PhD}$. They were asked to judge whether each of the items in a PSCAS measured the speaking component being studied in the classroom setting. It was recommended that ungrammatical points and some wordings that sounded awkward be changed and an English native speaker proofread the revised content. After the English native speaker proofread all the items, he 
suggested that two items namely, Item \# 24 "I keep thinking that other students are better at speaking English than I" and Item \# 25 "I always feel that the other students speak English better than I do" be deleted because they indirectly measure speaking anxiety, but directly measure self-perceived ability or self-efficacy instead. In addition, 32 third year students in the B.A (English) program, who were taking the public speaking course with the researcher were asked to read through the items of the Thai version and help make comments if they found the items confusing while reading. Of the thirty-one students, ten students made comments on the Thai version, but some of them said the Thai wordings of a PSCAS were explicitly clear. Some students recommended that minor changes of the wording of Items \# 6, 8 and 14 be made because they sounded unclear. Thereafter, the two items were omitted as suggested by the English native speaker and the Thai version wordings of some items were revised as suggested by the students.

\subsection{Internal Reliability}

To establish the internal consistency of a PSCAS Cronbach's alpha was used. Gravetter and Wallnau (1996) assert that the calculating of reliability of the questionnaire items using coefficient $(\alpha)$ is appropriate when the items are not scored right versus wrong. The internal consistency coefficient of the questionnaires completed by 76 second year students in the B Ed. (English) program turned out to be .84 , considered acceptable based on the broadly acceptable reliability coefficient of .70 (Fraenkel \& Wallen, 1993).

\subsection{Construct Validity}

Because the main purpose of the development of a PSCAS was to construct a one-dimensional measure of speaking component in the public speaking class, a factor analysis was employed to help select items to be included. Theoretically, a factor analysis is used to identify underlying variables, or factors, which account for the pattern of correlations within a set of observed variables. A factor analysis is commonly used for data reduction to identify a small number of factors explaining most of the variance which were observed in a much larger number of variables. As such, the Principal Axis Factoring method of extraction was conducted to examine the factor structure of the preliminary 23 -item public speaking class anxiety scale. An analysis was performed on responses to the preliminary 23 -item public speaking class anxiety scale by the subjects $(\mathrm{N}=76)$, second year Thepsatri Rajabhat University students in the B. Ed. (English) program in Thailand. The majority of these participants were women. The criteria used to determine the number of common factors to retain, including the eigenvalue $>1$ criterion, the factor loading $>.4$ criterion, the amount of common variance explained, and conceptual interpretability of the factor structure. The initial run of a factor analysis using varimax/orthogonal rotation showed an ambiguous structure, which could be justified by the fact that dimensions of anxiety experience were expected to covary. As thus, an oblique rotation (Oblimin) was employed to increase interpretability of the factors. Based on an oblique rotation in the second run, it showed that the Kaiser-Meyer-Olkin (KMO) measure of sampling adequacy attained a .78 value, which was far greater than the acceptable value of .6 and the Bartlett test of sphericity was $p=.00$, which was significant. Thus, the two tests (Bartlett test of sphericity and the KMO measurement of sampling adequacy) confirmed the suitability of the data and showed an acceptable level of reliability. The oblique rotation (Oblimin) produced six-factor with the Eigenvalue greater than one. The six -factor solutions accounted for $70.7 \%$ of the total variance. Table 2 shows the six extracted factors accounted for $70.7 \%$ of the total variance. 
Table 2. Factor Loadings, Communalities, Initial Eigenvalues and Percents of Variance for Six Principal Axis Factoring on a PSCAS

\begin{tabular}{|c|c|c|c|c|c|c|c|}
\hline item & Factor 1 & Factor 2 & Factor 3 & Factor 4 & Factor 5 & Factor 6 & $\mathrm{~h} 2$ \\
\hline 1 & & -.223 & $.431^{*}$ & & -.225 & .379 & .616 \\
\hline 2 & .370 & & .111 & -.148 & -.561 & .378 & .812 \\
\hline 3 & .220 & & -.118 & & -.124 & $.749 * *$ & .701 \\
\hline 4 & -.117 & & .239 & & & $.613 * *$ & .459 \\
\hline 5 & & $.629 * *$ & & -.322 & -.274 & -.175 & .647 \\
\hline 6 & .351 & & & -.593 & & .209 & .817 \\
\hline 7 & .198 & -.113 & & -.404 & .217 & $.435^{*}$ & .766 \\
\hline 8 & $.629 * *$ & & .121 & & -174 & & .470 \\
\hline 9 & & & $.569 *$ & -.132 & -.157 & .140 & .458 \\
\hline 10 & & $.795 * *$ & & .105 & .101 & & .650 \\
\hline 11 & $.703 * *$ & & & -.100 & & & .624 \\
\hline 12 & & $.619^{* *}$ & & & & & .427 \\
\hline 13 & $.624 * *$ & -.186 & .110 & & .108 & & .536 \\
\hline 14 & -.129 & $.792 * *$ & .140 & & & & .792 \\
\hline 15 & & .387 & & .343 & & & .300 \\
\hline 16 & & -.228 & & -.131 & & .249 & .292 \\
\hline 17 & $.568^{*}$ & & -.190 & -.170 & .147 & .261 & .656 \\
\hline 18 & $.574 *$ & -.214 & -.142 & -.272 & & & .616 \\
\hline 19 & & & .257 & -.728 & & & .761 \\
\hline 20 & .114 & & & -.192 & .248 & $.418^{*}$ & .433 \\
\hline 21 & $.800 * *$ & & & & .196 & .186 & 699 \\
\hline 22 & .189 & & .202 & -.238 & $.648 * *$ & .177 & .757 \\
\hline 23 & .209 & & $.817^{* *}$ & & .365 & & .905 \\
\hline \multicolumn{8}{|l|}{ Initial } \\
\hline Eigenvalue & 8.634 & 2.102 & 1.630 & 1.544 & 1.271 & 1.091 & \\
\hline \multicolumn{8}{|l|}{$\%$ of } \\
\hline variance & 37.537 & 9.137 & 7.085 & 6.712 & 5.526 & 4.745 & \\
\hline
\end{tabular}

The First Factor, accounting for $38 \%$ of the variance, received strong loading ( $>.6$ ) from four items, appreciable loadings from two items, and acceptable loading from 1 item. Those items with strong loadings (Items \# 8, 11, 13,21 ) and appreciable loadings (Items \# 17, 18) were related to communication apprehension demonstrated by (a) fear of negative evaluation as evidenced by feeling of being less competent than others (Item \# 8) and anxiety over being called on (Item \#11); (b) nervousness while waiting to speak English (Item \#18) and (c) bodily reactions towards speaking English (Items \# 17, 21). The only item with marginal loadings (>.3) was indicative of feelings of less competent than others (Item \# 6) and the other items obtained low loadings (Items \# 3, 7, 20, 22,23 ) and negative loadings (Items \# 4, 14).

Factor Two, accounting for $9.1 \%$ of the variance, were molded around speaking component with strong loadings (Items \# 5, 10,12,14), which were reflective of comfort in speaking English. The only item related to comfort in speaking English received marginal loadings (Item \# 15). The other items received low loadings (Items \# 1, 7, 13, 16,18 ) and negative loadings (Items \# 7, 16).

Factor Three, accounting for $7.08 \%$ of the variance, received strong loadings (>.6) from one item and appreciable loadings (.4-.5) from 2 items. The strong loadings (Item \# 23) and appreciable loadings (Items \# 9 and 1) were indicative of test anxiety as evidenced by fear of inadequate performance in speaking English. The other items obtained low loadings (Items \# 2, 4, 8, 13, 19, 22) and negative loadings (Items \# 3, 18, 17, 14).

Factor Four, accounting for $6.7 \%$ of the variance, received only positively marginal loadings from one item (Item \# 15), which seemed to be related to comfort in speaking English. The other items received low and negative loadings. Thus, in view of this, no label was attached to this factor because it did not seem to define an important dimension of the public speaking class scale. 
One item (Item \# 22) loaded strongly, one marginally (Item \# 23), six low (Items \# 7, 10, 13, 17, 20, 21) and 6 negatively (Items \# 1, 2, 3, 5, 8, 9) on Factor Five, which accounts for $5.5 \%$ of the variance. As there was only one item with strong loadings, there was no label attached to this factor.

The Last Factor, accounting for $4.7 \%$ of the variance, obtained strong loadings from two items (Items \# 3, 4), appreciable loadings from two items (Items \# 7, 20), and marginal loadings from two items (Items \# 1, 2). The other items, namely Items \# 6, 8, 16, 17, 22 received low loadings and the only item (Item \# 5) received negative loading. The items with strong loadings (Items \# 3,4) and with appreciable loadings (Items \# 7, 20) were indicative of anticipated anxious behaviors in speaking English, which are informative for communication apprehension.

As the aim of a factor analysis was to select items representing a measure of speaking anxiety in a public speaking class, in a practical sense, only items with positively appreciable loadings (loading of .40) found in a factor analysis were included in a PSCAS. That is to say, there were four factors molding around the speaking component, in which factor one (communication anxiety in a public speaking class) was the main construct, whereas the other factors were considered as subcomponents. Factor One was indicative of (a) fear of negative evaluation as evidenced by feelings of less competent than others (Item \# 8) and anxiety over being called (Item \# 11); (b) nervousness while waiting to speak English (Item \# 18) and (c) bodily reaction towards speaking English (Items \# 17, 21); Factor Two was reflective of comfort in speaking English, which was informative of the speaking component in the public speaking class (Items \# 5, 10, 12, 14); Factor Three was related to test anxiety, which was indicated by fear of inadequate performance in speaking English (Items \# 1, 9, 23); and Factor Six was indicative of anticipated anxious behaviors in speaking English (Items \# 3, 4, 7, 20), which were informative of communication apprehension in public speaking class. Thus, the construct of public speaking class anxiety consisted of elements of communication apprehension, test anxiety, fear of negative evaluation, and comfort in using English, which molding around the speaking component in a public speaking class. After selecting items based on the results of analysis of preliminary PSCAS using the Principal Axis Factoring method of extraction, the final version of a PSCAS resulted in 17 items. Table 3 presents items included in the final version of a PSCAS.

Table 3. A Final Version of a PSCAS

\begin{tabular}{|c|c|c|c|c|c|c|}
\hline \multirow{2}{*}{$\begin{array}{l}\text { Item } \\
\text { No }\end{array}$} & \multirow{2}{*}{$\begin{array}{l}\text { Statements adopted with minor adaptation in } \\
\text { wordings }\end{array}$} & \multicolumn{5}{|l|}{ Opinion } \\
\hline & & $\begin{array}{l}\text { (5) } \\
\text { Strongly } \\
\text { Agree }\end{array}$ & $\begin{array}{l}\text { (4) } \\
\text { Agree }\end{array}$ & $\begin{array}{l}\text { (3) } \\
\text { Undecided }\end{array}$ & $\begin{array}{l}\text { (2) } \\
\text { Disagree }\end{array}$ & $\begin{array}{l}\text { (1) } \\
\text { Strongly } \\
\text { Disagree }\end{array}$ \\
\hline 1 & $\begin{array}{l}\text { I never feel quite sure of myself while I am } \\
\text { speaking English. }\end{array}$ & & & & & \\
\hline 2 & $\begin{array}{l}\text { I start to panic when I have to speak English } \\
\text { without a preparation in advance. }\end{array}$ & & & & & \\
\hline 3 & $\begin{array}{l}\text { In a speaking class, I can get so nervous I forget } \\
\text { things I know. }\end{array}$ & & & & & \\
\hline 4 & I feel confident while I am speaking English. & & & & & \\
\hline 5 & $\begin{array}{l}\text { I get nervous and confused when I am speaking } \\
\text { English. }\end{array}$ & & & & & \\
\hline 6 & $\begin{array}{l}\text { I am afraid that other students will laugh at me } \\
\text { while I am speaking English. }\end{array}$ & & & & & \\
\hline 7 & $\begin{array}{l}\text { I get nervous when the English teacher asks me to } \\
\text { speak English which I have prepared in advance. }\end{array}$ & & & & & \\
\hline 8 & I have no fear of speaking English. & & & & & \\
\hline 9 & $\begin{array}{l}\text { I can feel my heart pounding when I am going to be } \\
\text { called on. }\end{array}$ & & & & & \\
\hline 10 & I feel relaxed while I am speaking English. & & & & & \\
\hline 11 & $\begin{array}{l}\text { It embarrasses me to volunteer to go out first to } \\
\text { speak English }\end{array}$ & & & & & \\
\hline 12 & $\begin{array}{l}\text { I face the prospect of speaking English with } \\
\text { confidence. }\end{array}$ & & & & & \\
\hline 13 & $\begin{array}{l}\text { Certain parts of my body feel very tense and rigid } \\
\text { while I am speaking English. }\end{array}$ & & & & & \\
\hline 14 & I feel anxious while I am waiting to speak English. & & & & & \\
\hline 15 & $\begin{array}{l}\text { I dislike using my voice and body expressively } \\
\text { while I am speaking English. }\end{array}$ & & & & & \\
\hline 16 & $\begin{array}{l}\text { I have trouble to coordinate my movements while I } \\
\text { am speaking English. }\end{array}$ & & & & & \\
\hline 17 & $\begin{array}{l}\text { Even if I am very well prepared, I feel anxious } \\
\text { about speaking English. }\end{array}$ & & & & & \\
\hline
\end{tabular}




\subsection{Levels of Public Speaking Class Anxiety Using a PSCAS}

According to the literature review, there were no precise guidelines to analyze the responses given to the existing foreign language anxiety scales. To analyze levels of anxiety using the FLCAS, Liu and Jackson (2008) suggested to multiply the point of the 33 item five-point Likert scale giving only a value of 5 (Strongly Agree), and then subtracting from the total multiplied scores from the total items of the scale (36). Thus, the FLCAS total multiplied scores were 180 from which was subtracted 36; scores higher than 144 were categorized as high anxiety, between 144-108 as medium anxiety, and less than 108 as low anxiety. Likewise, a PSCAS comprised 17 items, each of which was answered on a five-point Likert scale, ranging from 5 "Strongly Agree" to 1 "Strongly Disagree." Thus, the total multiplied scores of a PSCAS were 85 and then subtracted by 17; scores higher than 68 were categorized as high anxiety, between 68-51 as medium anxiety, and lower than 51 as low anxiety. To reveal levels of anxiety requiring the determination of the mean, Liu and Jackson (2008) suggested adjusting the values assigned to different alternatives from "Strongly Disagree" to "Strongly Agree." Namely, the items expressing positive attitudes had the values assigned to their alternatives reversed, so that the response "Strongly Disagree" received a score of 5 instead of 1 and vice versa. As such, Items \# 4, 8, 10, 12, of a PSCAS had the values reversed. In terms of anxiety levels based on mean, it revealed that mean scores which fall within the interval of 3-4 were categorized as medium anxiety level, below 3 as low anxiety level, and above 4 as high anxiety level, respectively.

\section{Pedagogical Implication}

To measure EFL speaking anxiety, the development of scale based on widely used existing language anxiety scales should be done because there are not any scales considered suitable to measure all dimensions of anxiety across contexts. Aida (1994) said that the use of a specific measure of oral skills may yield more profound relationships between language anxiety and achievement. Based on the literature described above, students in the Thai context reported that they felt most anxious when having to speak English and this coincides with Horwitz's (1995) statement that although students manifested little stress in the other aspects of language learning, many students specifically experienced anxiety triggers to speak publicly in the target language. Thus, with a measure of the developed PSCAS, students' levels of anxiety may be identified precisely, making teachers enable to address appropriate strategies to help alleviate such anxiety levels in EFL public speaking class. The present study is only a step forward in developing a PSCAS to measure EFL public speaking anxiety levels; therefore, further modification, refinement, and investigation about this scale is encouraged.

\section{Conclusion}

The main aim of this study was to develop an EFL public speaking anxiety scale (PSCAS) used specifically to tap speaking anxiety in an EFL public speaking class for English language learners. A PSCAS was developed based on critical appraisals of widely used existing foreign language classroom anxiety scales. The items of a PSCAS were adopted and adapted with minor wording changes and then were validated. A PSCAS yielded a respectable preliminary internal consistency at .84 after being piloted with 76 participants and it demonstrated a construct composition around the speaking component in a public speaking class setting. Thus, a PSCAS could be a potentially useful measure to help indicate EFL public speaking anxiety levels in EFL public speaking class.

\section{Acknowledgements}

The authors would like to acknowledge the Office of the Higher Education Commission, Ministry of Education Thailand, which provided full financial support through the "Strategic Scholarships Fellowships for Frontier Research Networks" program for the present study.

\section{References}

Aida, Y. (1994). Examination of Horwitz, Horwitz and Cope's construct of foreign language anxiety: The case of $\begin{array}{lllll}\text { students of Japanese. Modern Language Journal, } & \text { 78, 155-168. }\end{array}$ http://dx.doi.org/10.1111/j.1540-4781.1994.tb02026.x

Behnke, R. R., \& Sawyer, C. R. (1998). Conceptualizing speech anxiety as a dynamic trait. Southern Communication Journal, 63, 160-168. http://dx.doi.org/10.1080/10417949809373086

Boonkit, K. (2010). Enhancing the development of speaking skills for non-native speakers of English. Procedia Social and Behavioral Sciences, 2, 1305-1309. http://dx.doi.org/10.1016/j.sbspro.2010.03.191

Bunrueng, P. (2008). Anxiety in studying English for Communication of Loei Rajabhat University Students. Proceedings from International Conference of Educational Research (ICER) on Learning Communities for Sustainable 
http://ednet.kku.ac.th/ research/ICER/ICER_2008_Proceeding/full\%20paper/Bunreung_Pongthep.pdf

Chen, T., \& Chang, G. (2004). The relationship between language anxiety and learning difficulties. Foreign Language Annals, 37, 279-289. http://dx.doi.org/10.1111/j.1944-9720.2004.tb02200.x

Clevenger, T., \& Halvorson, S. K. (1992). Converting the PRCA-State Version 2 to the Speech Anxiety Scale. Tallahassee, The Florida State University.

Daly, J. (1991). Understanding communication apprehension: An introduction for language educators. In E. K. Horwitz, \& D. J. Young (Eds.), Language anxiety: From theory and research to classroom implications (pp. 3-14). Upper Saddle River, NJ: Prentice Hall.

Forman, R. (2005). Teaching ELT in Thailand: A bilingual study. Unpublished doctoral dissertation, University of Technology, Sydney.

Fraenkel, J. R., \& Wallen, N. E. (1993). How to design and evaluate research in education. New York: McGraw Hill.

Frantz, J., Marlow, A., \& Wathen, J. (2005). Communication apprehension and its relationship to gender and college year. Journal of Undergraduate Research, MSU-Mankato, 5, 1-11.

Gardner, R. C. (1980). On the validity of affective variables in second language acquisition: Conceptual, contextual and statistical considerations. Language Learning, 30(2), 255-270. http://dx.doi.org/10.1111/j.1467-1770.1980.tb00318.x

Gardner, R. C., \& MacIntyre, P. D. (1993). On the measurement of affective variables in second language learning. Language Learning, 43, 157-194. http://dx.doi.org/10.1111/j.1467-1770.1992.tb00714.x

Gilkinson, H. (1942). Social fears as reported by students in college speech classes. Speech Monographs, 9 , 141-160. http://dx.doi.org/10.1080/03637754209390068

Gravetter, F. J., \& Wallnau, L. B. (1996). Statistics for behavioral sciences: A first course of students of psychology and education. Minneapolis: West Pub. Co.

Horwitz, E. K., Horwitz, M. B., \& Cope J. A. (1986). Foreign language classroom anxiety. Modern Language Journal, 70, 125-132. http://dx.doi.org/10.1111/j.1540-4781.1986.tb05256.x

Horwitz, E. K., \& Young, D. (1991). Language anxiety: From theory and research to classroom implications. Upper Saddle River, NJ: Prentice Hall.

Kearney, P., Beatty, M. J., Plax, T. G., \& Mcroskey, J. C. (1984). Factor analysis of the Rathus assertiveness schedule and the personal report of communication apprehension-24: Replication and Extension. Psychological Reports, 54, 851-854. http://dx.doi.org/10.2466/pr0.1984.54.3.851

Khamkhien, A. (2010). Teaching English speaking and English speaking tests in the Thai context: A reflection from Thai perspective. English Language Teaching, 3(2), 184-190.

Kim, S. Y. (1998). Affective experiences of Korean college students in different instructional contexts: Anxiety and motivation in reading and conversation courses. Unpublished doctoral dissertation, The University of Texas, Austin.

Liu, M., \& Jackson, J. (2008). An exploration of Chinese EFL learners' unwillingness to communicate and foreign language anxiety. The Modern Language Journal, 92, 71-86. http://dx.doi.org/10.1111/j.1540-4781.2008.00687.x

MacIntyre, P. D., \& Gardner. R. C. (1991). Anxiety and second language learning: Toward a Theoretical clarification. In E. K. Horwitz, \& D. J. Young (Ed.), Language anxiety: From theory and research to classroom implications (pp. 41-53). Englewood Cliffs, NJ: Prentice Hall.

McCroskey, J. C. (1970). Measures of communication-bound anxiety. Speech Monograph, 37, 269-277. http://dx.doi.org/10.1080/03637757009375677

McCroskey, J. C. (1978). Validity of the PRCA as an index of oral communication apprehension. Communication Monographs, 45, 192-203. http://dx.doi.org/10.1080/03637757809375965

McCroskey, J. C. (1982). Oral communication apprehension: A reconceptualization. In M. Burgoon (Ed.), Communication Yearbook 6 (pp. 136-170). Beverly Hills, CA: Sage Publications.

McCroskey, J. C., Beatty, M. J., Kearney, P., \& Plax, T. G. (1985). The content Validity of PRCA-24 as a measure of communication apprehension across communication contexts. Communication Quarterly, 33(3), 
165-173. http://dx.doi.org/10.1080/01463378509369595

McCroskey, J. C., \& Richmond, V. P. (1992). Communication apprehension and shyness: Conceptual and operational distinction. Central States Speech Journal, 33, 458-468. http://dx.doi.org/10.1080/10510978209388452

Pérez-Paredes, P. F., \& Martínez-Sánchez, F. (2000-2001). A Spanish version of the foreign language classroom anxiety scale: Revisiting Aida's factor analysis. RESLA, 14, 337-352.

Philips, E. M. (1992). The effects of language anxiety on students' oral test performance and attitudes: Modern Language Journal, 76, 14-26. http://dx.doi.org/10.1111/j.1540-4781.1992.tb02573.x

Pribyl, C. B., Keaten, J., \& Sakamoto, M. (2001). The effectiveness of a skill-based program in reducing public speaking anxiety. Japanese Psychological Research, 43(3), 148-155. http://dx.doi.org/10.1111/1468-5884.t01-1-00171

Price, M. L. (1991). The subjective experience of foreign language anxiety: Interviews with highly anxious students. In E. K. Horwitz, \& D. J. Young (Eds.), Language Anxiety: From theory and research to classroom implications (pp. 101-108). Englewood Cliffs, NJ: Prentice-Hall.

Scovel, T. (1978). The effect of affect on foreign language learning: A review of the anxiety research. Language Learning, 28, 129-142. http://dx.doi.org/10.1111/j.1467-1770.1978.tb00309.x

Sethi, A. (2006). English language anxiety and self efficacy in relation to academic performance in undergraduate students. Unpublished master's thesis. Assumption University, Bangkok.

Sparks, R. L., \& Ganschow, L. (1991). Foreign language learning differences: Affective or native language $\begin{array}{lllll}\text { aptitude differences? Modern } & \text { Language }\end{array}$ http://dx.doi.org/10.1111/j.1540-4781.1991.tb01076.x

Tananuraksakul, N. (2011). Power relations in pedagogy: A constraint on EFL speakers' identity confidence and identity anxiety. Proceedings from $2^{\text {nd }}$ International Conference on Foreign Language Learning and Teaching. Bangkok.

Tasee, P. (2009). Factors affecting English major students anxiety about speaking English. Unpublished doctoral dissertation. Suranaree University of Technology, Nakhon Ratchasima.

Tóth, Z. (2008). A foreign language anxiety scale for Hungarian learners of English. WoPal, 2, 55-78.

Udomkit, J. (2003). Communication anxiety for the basic signal officers in the English classroom at the Signal school. Unpublished master's thesis. Mahidol University, Bangkok.

Vogely, A. (1999). Addressing listening comprehension anxiety. In Young, D. J. (Ed.), Affect in foreign language and second language learning: A practical guide to creating a low-anxiety classroom atmosphere (pp. 106-123). Boston, McGraw Hill.

Wiriyachitra, A. (2003). Thai teachers' roles in teaching English: Motivating students and guiding their learning. Thai TESOL Focus, 16(2), 25-27.

Young, D. J. (1986). The relationship between anxiety and foreign language oral proficiency ratings. Foreign Language Annals, 19, 439-45. http://dx.doi.org/10.1111/j.1944-9720.1986.tb01032.x 